\title{
The Petroleum Exploitation and Pollution in Ogoni, Rivers State, Nigeria: The Community Perspective
}

\author{
Tombari Bodo (PhD) \\ Department of Geography and Natural Resource Management, Faculty of \\ Social Sciences, University of Uyo, Uyo, Akwa Ibom State, Nigeria
}

Lekpa Kingdom David (PhD)

Department of Anatomy, Faculty of Medical Sciences, College of Health Sciences, University of Port Harcourt, Nigeria

Doi:10.19044/esj.2018.v14n32p197 URL:http://dx.doi.org/10.19044/esj.2018.v14n32p197

\begin{abstract}
The aim of this paper was to examine community perspective to petroleum exploitation and pollution in Ogoni, Rivers State. To achieve this aim, the objective was to determine the extent to which the pollution of the environment has affected the people's views of usefulness of the resources in their communities. The survey design method was employed. Purposive sampling technique was used to select 21 oil bearing communities from the four Local Government Areas (LGAs) of Ogoniland. The data were collected using interviews, focus group discussions, oral testimonies and questionnaires. Being qualitative; transcriptions, rewriting and coding were employed in data analysis, except for the questionnaires which adopted descriptive statistical methods. Results showed that majority of the people have not benefitted from the petroleum resources in their communities. It was revealed that pollution has changed the people's views of the usefulness of petroleum resources, as they clearly see the resources in their communities as a curse. However, many communities believed that there was no sincerity on the part of their leaders, as the dividends claimed to be given by the multinational oil companies (MNOCs) for the welfare and benefit of the people were not visible. It is recommended that in order to change the perception of the people toward petroleum exploitation, the MNOCs should massively develop the host communities with basic social amenities and deal directly with the land owners whose portions of land are directly affected and not through the chiefs or the Community Based Organisations (CBOs).
\end{abstract}

Keywords: Petroleum, exploitation, pollution and usefulness. 


\section{Introduction}

A resource is considered useful when it is beneficial to the indigenous communities or state where it is found (Dominic, 1999). A resource can be useful in one area and may not be useful in another area (Baghebo, 2012). Petroleum resources are the predominant source of revenue and foreign exchange in Nigeria (Bawa and Mohammed, 2007). Petroleum exploitation and the pollution of the environment have become regular occurrence in the Niger Delta.

It has been shown empirically and analysed in previous studies that countries rich in natural resources tend to perform poorly in terms of developmental improvement and growth (Auty 1994b, 2001a, 2001b; Gelb 1998; Sachs and Warner 1995). Some researchers have noted that revenue from petroleum resources can bring not only conflict but corruption and mismanagement (Frankel, 2010; Eregha and Mesagan 2016). It has been reported that the governments in some countries with abundant natural resources, do not give proper accountability of the revenue derived from it (Tsui, 2011; Andersen and Ross, 2013). Karl (2004) notes that "one of the most important social consequences of the resource curse is that oil-exporting countries have unusually high poverty rates, poor health care, high mortality and poor educational performance given their revenue outcomes that contradict the beliefs about what should happen within oil-exporting countries" (p. 663). A research project on 95 developing countries, conducted in 1997 by Sachs and Warner, reveals that there was a clear negative relationship between natural resource based exports (agriculture, minerals and fuels) and growth in the period 1970-90. In their survey, they discovered that only Malaysia and Mauritius sustained a two percent per annum growth during 1970-80, thereby portraying countries with enormous resources as being under a curse (Sachs and Warner, 1997).Wright and Czelusta (2002), on the other hand, pointed out the United States of America (USA) as an example of a resource-rich country which avoided the curse. In another study, it was reported that people support the view that poor per capita performance was "especially manifest in mineral exporting countries" (Mikesell, 1997; Gelb, 1998). Some of the OPEC countries also showed a negative relationship between oil revenue derived from oil and GNP in the long run and, in these countries; there had been no tangible sustainable investment from the oil revenue (Shams, 1989). Saudi Arabia, Mexico and Venezuela are singled out as having lower than average annual growth rates of GDP (Mikesell, 1997).

In another study, it was stated that resource abundance tends to worsen income inequality (Auty, 1994b; Fields, 1989; Bulmer-Thomas, 1994). In yet another study, it was shown that resource abundance is often associated with greater conflict in a society (Collier and Hoffler, 2004; Ross, 2001). Several studies on perception of natural resources revealed that oil is being perceived as non-beneficial (Akpabio and Akpan, 2010; Baghebo, 2012; Baghebo and 
Atima, 2013; Bawa and Mohammed, 2007). Juan Pablo Alfonzo, a prominent Venezuelan diplomat, called oil the devil's excrement and a curse to any society that has it (Perouse de montclos, 2014). Sachs and Warner (2001) noted that the decline in manufacturing is one of the consequences of natural resource availability. It is also reported that the oil rich communities in the Niger Delta resort to conflict as the only way of expressing grievances (Akapbio and Akpan, 2010; Akpan and Akpabio, 2009).

While the abundance of oil may be regarded as disadvantageous, the absence of it, on the other hand, can equally prove to be unfortunate (James, 2015). The economic growth in some oil producing states shows that oil can contribute to economic and political stability when managed properly. Indeed, Agwu 2013 rightly asserts that the "exploitation activities of oil processing companies open up the Niger Delta to environmental pollution, greenhouse effect, habitat destruction, soil erosion and flooding". The question, therefore, is: can these continuous incidents of pollution influence the behaviour and perception of the people in the region? This study aims to evaluate and ascertain whether pollution has affected the people's perception of the usefulness of petroleum resources.

\section{Objective of the Study}

This study was designed to carefully analyse views and opinions of the people of Ogoniland about the environmental degradation of their space due to petroleum exploitation. The focus of this study was to determine whether the pollution of the environment has affected the people's views of usefulness of the resources in their communities.

\section{Research Hypothesis}

It is hypothesized that: The pollution of the environment by petroleum exploitation has affected the people's views of the usefulness of the resources in their communities.

\section{Study Area}

The Ogoni people are among the several ethnic minorities in River State, Nigeria, that occupy a territory of approximately 404 square miles, which forms the part of the Eastern Niger Delta, between the Imo River on the East and North. The area lies between latitudes $4^{0} .05^{1}$ and $4^{0} .20^{1}$ North and longitudes $7^{0} .10^{1}$ and $7^{0} .30^{1}$ East (Agbonofo, 2009). 


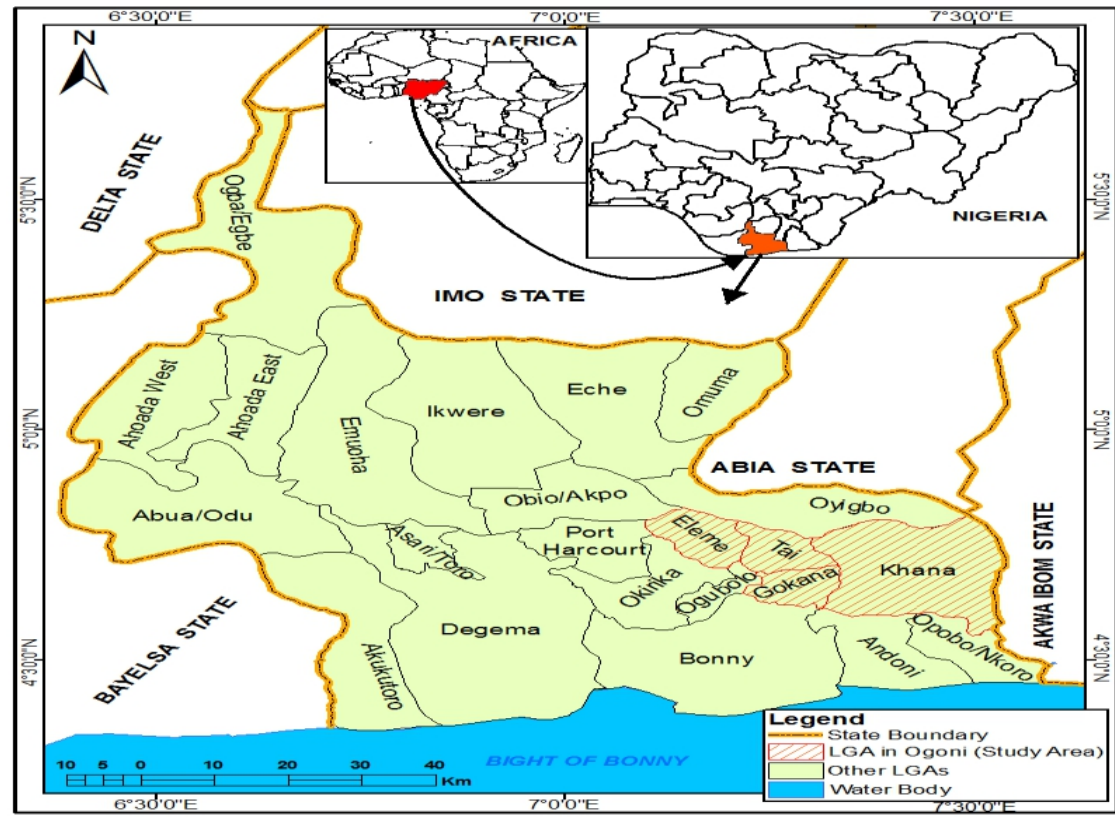

Figure 1.: The LGAs in Ogoni on the Map of Rivers State (Source: Rivers State Surveyor General Office, 2016)

The population of the Ogoni environment is approximately 950,000 according to the 2006 population census of Nigeria. Owing to their agricultural economy and an increasing population, most of the rainforest that once covered the area has been altered or removed for farming, which has over the years caused larger Ogoni villages to grow together and form towns, some of which are as large as 10,000 people (UNEP, 2011). Ogoniland is made up of six kingdoms -Babbe, Eleme, Gokana, Ken-Khana, Nyo-Khana and Tai -with four different although related languages, and is united under one town Bori, which is the capital.

Despite Christianisation, many aspects of Ogoni indigenous culture and religion are still evident. They have their own distinct culture in which land was traditionally seen as a god and worshipped (UNEP, 2011). Similarly, the Ogoni people have a tradition and custom that is deeply rooted in nature and this helped them to protect and preserve the environment for generations (UNEP, 2011). The land on which they live and the rivers which surround them are considered, not just as natural resources for exploitation, but viewed with deep spiritual significance. While the Ogoni communities may appear similar to the outside world, they have distinctive features, including traditional institutional structures, languages and cultural features (Legbosi, 2007).

Despite this high population density, the extraordinary fertility of the Niger Delta soil has historically allowed the Ogoni people to make good living through subsistence farming and fishing. However, it is reported that their livelihood is being threatened (Tanee and Love, 2009). 
The Ogoni people gained global prominence in the past two decades as a result of their agitation over acclaimed neglect and deprivation by the Federal Government of Nigeria as well as the level of environmental degradation in the region (Mmom and Igbuku, 2015). The Ogoni people are said to have been victims of human rights violation for many years (Mmon and Igbuku, 2015). In 1956, Royal Dutch in collaboration with the British government found a commercially viable oil field in Ogoni and in other parts of the Niger Delta region and began oil production in 1958 (Mmom and Igbuku, 2015). Exploitation and production of crude oil continued in Ogoniland up till 1993 when the people rose up in opposition with protests and agitation due to massive environmental pollution of the land (Mmon and Igbuku).

\section{Materials and Methods}

The population figures of Ogoni is 950,532 (comprising 218,200; 261,570; 336,267 and 134,495 for Eleme, Gokana, Khana and Tai Local Government Areas respectively) according to the 2006 population census of Nigeria (NPC, 2006). In order to determine the projected population for the LGAs in Ogoni in 2016, the extrapolation method was adopted using the National Population Commission data of 2006 as the base year (Ogbanga, 2015).To determine the sample size from the population, the Taro Yamane formula was used (Uzoagulu, 1998).

Table 1: Projected Population of the LGAs in Ogoni

\begin{tabular}{|l|l|l|}
\hline LGAs & 2006 Population & $\begin{array}{l}\text { Projected Population } \\
\mathbf{( 2 0 1 6 )}\end{array}$ \\
\hline Eleme & 218,200 & 298,986 \\
\hline Gokana & 261,570 & 358,413 \\
\hline Khana & 336,267 & 460,766 \\
\hline Tai & 137,495 & 184,290 \\
\hline
\end{tabular}

Purposive sampling technique was used to determine the sample for each of the chosen communities in the LGAs. Based on the field survey and the UNEP environmental evaluation and assessment of Ogoniland (UNEP, 2011), there are 30 oil bearing or producing communities in Ogoniland. Out of the 30 oil bearing communities, 21 were selected based on accessibility to the main lines of communication and the security of the communities as observed during reconnaissance survey. The respondents for the study comprised adult citizens who were 18 years and above engaged in any occupation, that were resident within the Ogoni oil-bearing communities.

The research adopted a qualitative approach which is most appropriate for exploring the perception of a people on how they feel about a phenomenon or situation that has affected them (Gallimore, 1996; Lindlof and Taylor, 2002; Harding, 2013). Hence, data were collected through structured questionnaires, informal interviews, oral testimonies, focus group discussions and field 
observations as shown on Table 2. Being qualitative; transcription, transcribing, rewriting and coding were employed in data analysis, except for the questionnaires which adopted descriptive statistical methods such as frequency counts, percentages, means scores.

In this study, the survey type of design was used. The design is considered appropriate for the study because according to Nworgu (2006), survey research is one which a group of people or items is studied by collecting and analyzing data from only a few people or items considered to be representative of the entire group. This was applicable to this study.

Table 2: Data Collection Distribution

\begin{tabular}{|l|l|l|l|l|}
\hline LGA & Interview & Focus Group & Oral Testimony & Questionnaire \\
\hline Eleme & 3 & 2 & 1 & 100 \\
\hline Gokana & 3 & 2 & 1 & 100 \\
\hline Khana & 3 & 2 & 1 & 94 \\
\hline Tai & 3 & 2 & 1 & 100 \\
\hline
\end{tabular}

Source: Fieldwork, 2017.

\section{Results and Discussions}

\section{Demographic Characteristics of Sampled Population}

The sex distribution in the study area revealed that about $53.5 \%$ are males while $46.5 \%$ (186) are females. The data on the age of the respondents revealed that the ages of the respondents are highest at 21-30 (28.50\%) and lowest at ages above $60(7.50 \%)$ as shown on table 3 . This is also in conformity with the general demographic population distribution of Nigeria as represented by the 2006 population census, which stipulates that there is greater percentage of males than females. Majority of the population under study falls within the youth bracket; with a higher percentage of the youths within $17.50 \%, 28.50 \%$ and $13.75 \%$ for ages less than 21 years, 21-30 years and 31-40 years respectively. The result is in correlation with the findings of Ogbanga (2015) that cited that majority of the respondents in Rivers State were within the age bracket of 18-30 years. The result from the survey of the respondents on their occupation revealed that $31.75 \%$ are farmers, $23.75 \%$ are fishermen, $15.50 \%$ are traders, $7.5 \%$ are civil servants, and $11.0 \%$ are artisans while every other occupation (touting, conductors, bunkering, drivers etc) constituted $11.25 \%$ as shown on Table 3.

This clearly shows that the main occupation of the people in the study area comprises farming and fishing. This conforms to the statement of the Human rights activist, Kenule Saro-Wiwa, 'the high population density and the extraordinary fertility of the Niger Delta have historically allowed the Ogoni to make good living as subsistence farmers and fishing people'(SaroWiwa, 1995).

The data collected on the educational qualification of the respondents revealed that $8 \%$ of the respondents have First School Leaving Certificate, 
$23.75 \%$ have O level, 6.25\% have OND, 20\% have B.Sc or HND degrees, 5\% have Master's degrees, $1.50 \%$ has Doctorate degrees and $12.75 \%$ of the respondents have no form of formal education.

The respondents are fairly educated considering that about $20 \%$ of the sampled population are First degree holders and $23.75 \%$ are O level holders. In the aspect of marital status, the data showed that $27.75 \%$ of the respondents are married, $0.75 \%$ is divorced, 53.50 are single and $18 \%$ fall into the category of widow or widower. This data indicated that more than half of the respondents were youths.

The monthly income distribution of the respondents shows that $63.25 \%$ earn less than $\mathrm{N} 10,000 ; 15.50 \%$ earn between N10,000-N20,000; $13 \%$ earn between $\mathrm{N} 20,000-\mathrm{N} 30,000 ; 3.75 \%$ earn between N30,000-N40,000; 3\% earn between $\mathrm{N} 40,000-\mathrm{N} 50,000$ and only $1.50 \%$ earn above N50,000. This goes to show that majority of the sampled population (63.25\%) are low income earners. The low level of income in the study area, maybe due to the loss of their major sources of income as a result of the pollution of their environment through petroleum exploitation.

Table 3: Socio-economic Characteristics of Respondents

\begin{tabular}{|l|l|l|}
\hline \multicolumn{1}{|c|}{ Variable } & \multicolumn{1}{c|}{ Frequency } & \multicolumn{1}{c|}{ Percentage } \\
\hline \multicolumn{1}{|c|}{ Male } & \multicolumn{1}{c|}{214} & \\
\hline \multicolumn{1}{|c|}{ Female } & \multicolumn{1}{c|}{186} & \\
\hline & & 46.5 \\
\hline Age Range & 70 & 17.50 \\
\hline$<21$ & 114 & 28.50 \\
\hline $21-30$ & 90 & 22.50 \\
\hline $31-40$ & 55 & 13.75 \\
\hline $41-50$ & 41 & 10.25 \\
$51-60$ & & \\
& 30 & 7.50 \\
$>60$ & & \\
& & 31.75 \\
\hline Occupation & 127 & 23.75 \\
\hline Farming & 95 & 15.50 \\
\hline Fishing & 62 & 7.50 \\
Trading & 22 & 11.00 \\
\hline Civil Service & 44 & 11.25 \\
\hline Artisan & 45 & \\
\hline Others & & 21.25 \\
\hline Educational Qualification & 85 & 23.75 \\
\hline F.S.L.C & 95 & 6.25 \\
\hline O-Level & 25 & 20.00 \\
\hline OND & 80 & 5.00 \\
\hline BSc/HND & 20 & 1.50 \\
\hline MSc & 6 & 9.50 \\
\hline PhD & 38 & \\
\hline Others & & \\
\hline & & \\
\hline
\end{tabular}




\begin{tabular}{|l|l|l|}
\hline None & 51 & 12.75 \\
\hline Marital Status & & \\
\hline Married & 111 & 27.75 \\
\hline Divorced & 3 & 0.75 \\
\hline Single & 214 & 53.50 \\
\hline Widow/Widower & 72 & 18.00 \\
\hline $\begin{array}{l}\text { Monthly Income (Currency- } \\
\text { Naira) }\end{array}$ & & \\
\hline$<$ N10,000 & 253 & 63.25 \\
\hline N10,000-N20,000 & 62 & 15.50 \\
\hline N20,000-N30,000 & 52 & 13.00 \\
\hline N30,000-N40,000 & 15 & 3.75 \\
\hline N40,000-N50,000 & 12 & 3.00 \\
\hline$>$ N50,000 & 6 & 1.50 \\
\hline
\end{tabular}

Source: Fieldwork, 2017

\section{Usefulness of Petroleum Resources}

Data was collected to find out whether petroleum exploitation in the study area has affected the people's views of the usefulness of petroleum resources in their communities. At first, respondents were asked to give a cumulative estimate of how much in value (using the local currency, Naira) they have benefitted from petroleum resources. $6.75 \%$ of the respondents said they have received benefits worth less than N10,000; $1 \%$ have received $\mathrm{N} 10,000-\mathrm{N} 20,000 ; 0.5 \%$ have received $\mathrm{N} 20,000-\mathrm{N} 30,000 ; 0.25 \%$ have received $\mathrm{N} 30,000-\mathrm{N} 40,000 ; 0.25 \%$ have received above $\mathrm{N} 40,000$ and $91.25 \%$ of the respondents claimed not to have received any form of financial benefit. This result revealed that majority of the respondents $(91.25 \%)$ have not benefitted from the petroleum resources in their environment (See Table 4).

The result from the oral testimony by King Letam Doba of Kala Kingdom further emphasises the claims of the respondents from the questionnaire data, "I have never benefitted from the resources in my environment in anyway". In the focus group meeting held in the Community Primary School 1, Biara Assembly Hall, both Mrs. Ledibari Menegbo and Mr. Anthony Vurasi declared that oil has never benefitted anybody in their families. Only Mrs. Ziganu Moses argued otherwise that the paramount rulers and the chiefs were given monies on a monthly basis for onward distribution to the community dwellers but they have always kept it for themselves. Moreover, when we contacted the village head (whose name is withheld for security reasons) of one of the communities in the study area, concerning these allegations of keeping back monies donated by MNOCs for community consumption, he confirmed that the Shell Petroleum Development Company (SPDC) has been giving monies to some highly placed chiefs for years as loyalties to their thrones and for their future support on returning to Ogoniland, but these monies have never been and are not for sharing but for themselves. 
He concluded that he had applied for continuous payment after he was paid once (amount undisclosed) but SPDC had not responded up till the time that this study was carried out. In an oral interview, Mr. Batombari Gimah of Bera community emphasized that, "Oil resources is supposed to bring much gain to the people of Ogoni but unfortunately, oil has not benefitted anyone anything".

Table 4: Multiple Responses on the Usefulness of Petroleum Resources

\begin{tabular}{|l|l|l|}
\hline Questions & Frequency & $\%$ \\
\hline $\begin{array}{l}\text { How much have you benefitted } \\
\text { petrom } \\
\text { (Currency=Naira) }\end{array}$ & & \\
\hline$<10,000$ & 27 & 6.75 \\
\hline $10,000-20,000$ & 4 & 1 \\
\hline $20,000-30,000$ & 2 & 0.5 \\
\hline $30,000-40,000$ & 1 & 0.25 \\
\hline Above 40,000 & 1 & 0.25 \\
\hline None & 365 & 91.25 \\
\hline $\begin{array}{l}\text { Do you see petroleum resources as } \\
\text { a blessing? } \\
\text { YES, due to: }\end{array}$ & & \\
\hline Adequate compensation & 9 & 2.25 \\
\hline Visible dev. Projects & 0 & 0 \\
\hline Employment/Scholarships & 0 & 0 \\
\hline $\begin{array}{l}\text { Others (government presence or } \\
\text { attention) }\end{array}$ & 15 & 3.75 \\
\hline NO, due to: & & \\
\hline Environmental pollution & 364 & 91 \\
\hline Lack of any benefits & 84 & 21 \\
\hline Corruption of community leaders & 311 & 77 \\
\hline Unemployment & 364 & 91 \\
\hline $\begin{array}{l}\text { Others (series of crisis, violence, } \\
\text { sicknesses and deaths) }\end{array}$ & 15 & 3.75 \\
\hline $\begin{array}{l}\text { Has pollution of the environment } \\
\text { changed your views on the } \\
\text { usefulness of petroleum resources? }\end{array}$ & & \\
\hline YES & 399 & 99.75 \\
\hline NO & 1 & 0.25 \\
\hline $\begin{array}{l}\text { Has pollution affected your } \\
\text { occupation and livelihood? }\end{array}$ & & \\
\hline YES & 395 & 98.75 \\
\hline NO & 5 & 1.25 \\
\hline
\end{tabular}

Source: Fieldwork, 2017 
The respondents were further asked whether they see petroleum resources as a blessing (See Table 4). Only 6\% of the respondents see petroleum resources as a blessing with $2.25 \%$ of this population having adequate compensation as the reason for their stance while $3.75 \%$ feel it is a blessing due to government attention or presence in the community. On the other hand, most of the respondents do not see petroleum resources as a blessing with $91 \%$ of the respondents tying it to the degradation of their environment; $21 \%$ of the respondents feel it is not a blessing since they have not derived any benefit from it; $77 \%$ of the population said the corruption of the community leaders has made these resources not to be a blessing to them at all. Another group of respondents $(91 \%)$ named unemployment as the reason why they do not see petroleum resources as a blessing. The last group of respondents (15\%) believe that petroleum resources brought about violence, sicknesses and untimely deaths within the communities.

In one of the oral interviews conducted in the course of the study, $\mathrm{Mr}$. Batombari Gimah of Bera community stated unequivocally that, "Oil is a curse to the Ogoni people". In the focus group meeting at Eleme Local Government Council Secretariat, one of the youths, Mr. Kpoge Poronem said, "there are deaths, violence and oil related crisis all over the community. Oil is indeed a disaster and a curse". All other members of the focus group agreed with this declaration.

The data streamlined to ascertain whether pollution has changed their views of the usefulness of petroleum resources revealed that $99.75 \%$ of the respondents do not see petroleum resources as being useful. Only $1.25 \%$ of the respondents think otherwise (see Table 4). In an oral interview, Mr. Ngara Barikula of Mogho community in Gokana LGA declared that, "petroleum resources are an outright curse". In another interview, Mrs. Barieela Giadom said, "it would have been better if we had only our farmlands and rivers. Petroleum exploitation has made our lands and rivers useless".

$98.75 \%$ of the respondents affirmed that pollution has changed their primary occupation while $1.25 \%$ claimed that pollution has not changed their occupation or sources of livelihood. In an oral interview, Mrs. Barieeba Giadom explained that most of the youths are jobless because of the pollution of the environment. She continued by saying that their farmlands are now barren and rivers are poisoned due to series of oil spills. A farmer, Mr Beage Lekpa of Bera community, in another interview, explained that having lost his primary occupation due to pollution, he was left with no choice but to set up a provision store in order to survive.

Hypothesis: It was hypothesized that the pollution of the environment by petroleum has affected the people's views of the usefulness of the resource in their environment.

King Letam Doba of Kala kingdom remarked in his oral testimony, "I 
have not benefitted anything from the oil exploitation in my community. Rather, we have a polluted environment and crises". From our field observation, we observed that most of the Ogoni communities are tense and insecure. Most of the arguments and protests within the communities are either as a result of environmental degradation or are politically motivated. However, the general feeling about petroleum resources within the communities is that natives cannot see the reward from the years of oil exploitation on their land. The challenge in this context is not that the pollution of the environment has shielded them from seeing any form of reward, but that there are no visible noteworthy benefits despite the damages caused by petroleum exploitation. Mr. Batombari Gimah in an interview remarked, "We now all believe that this oil in our communities is the cause of our poverty and hardship. So all we want to do is fight back". The comment by Mr. Batombari is a clear indication of how the pollution of the environment has adversely influenced the people's view of petroleum resources within their native space. Mr. Ngara Barikuma declared in an interview that "if there are any benefits, it will be the loss of farmlands and the polluted environment which certainly cannot be called benefits". The loss of their primary occupation of farming and fishing contributed to the perception of the natural resource as a curse. Mr. Beage Lekpa, in another interview, said "the people now believe that the multinational oil companies are the enemies of the community and that oil has brought untold hardship to the natives". The field survey revealed that the people see SPDC as the chief culprit of the pollution and claimed that this is the reason why they were ejected from their land. Many of the respondents accused the SPDC for the continuous deterioration of their environment, as they are convinced beyond all reasonable doubt that in order to avert proper remediation of their land, SPDC has since engaged in lobbying their chiefs and some militant groups with cash gifts and other undisclosed privileges.

The results from the questionnaire data further shows that the pollution of the environment has affected the people's perception of the usefulness of the resource as $99.75 \%$ of the respondents see oil as not having been beneficial to them (see Table 4). Many of the respondents decried the daily deterioration of their environment and the absence of any basic amenities but a weight of abject poverty in which they live.

From the analysis of the results as explained above, it is clear that the pollution of the environment has greatly influenced the people's perception of the usefulness of the resources in their environment, as they now see petroleum resources as a curse. Thus, the hypothesis stands true and correct.

\section{Summary}

The Ogoni people clearly see the petroleum resources in their community as a curse. This assertion was made clear in their responses on table 
4, where $91 \%$ of the respondents no longer see the resource as a blessing. The people have not benefitted anything from the petroleum resources available, even when their environment is constantly being polluted. This is not supposed to be so, considering the amount of dividends the multinational oil companies claim to have given for the benefit and the wellbeing of the people of the Niger Delta (Moffat and Olof, 1995). Under normal circumstances, resources are supposed to be beneficial to the indigenous communities where they are found (Perouse de Montclos, 2014).

This perception of the Ogoni people on their resources being a curse conforms to the works of other scholars that equally see oil as a curse (Collier and Hoffler, 2004; James, 2015). The serious hatred and grievances of the respondents for petroleum resources is due to environmental pollution, lack of benefits, corruption of community leaders and unemployment (See table 3). Their claims are in agreement with the declaration of other scholars that believe that oil revenue only increases the sufferings of the indigenous community people and puts money in the pockets of the corrupt leaders, fuelling grievances and violence in the communities (Ezirim, 2011; NwajiakuDahou, 2012; Ugochukwu and Ertel, 2008)

The Ogonis are a hardworking people that are blessed with fertile lands and running rivers (Saro-Wiwa, 1995). However, if the communities in Ogoni depend solely on their lands and rivers for their livelihood, then the pollution of their environment could make them jobless, depriving them of their primary occupation which is farming and fishing (See table 3). When their livelihood is lost, youths could engage in other social vices that are not legitimate like bunkering, touting, armed robbery and militancy or violent clashes with the MNOC (Aghalino, 2009; Collier and Hoffler, 2004; Feleti, 2010; Watt, 2009). This study shows clearly that the unfavourable condition or suffering of a people can influence their perception of things. In this case, the pollution of the environment over a long period of time has made the people not to see petroleum resources as being useful anymore.

\section{Conclusion}

The result from this study conducted reveals that petroleum resources have become useless to the people and all they want presently is the rehabilitation of their portions of land and river resources to enable them go back to their occupation and livelihood. The people see their community leaders (elders and chiefs) and the leaders of the indigenous organisations as being corrupt. Moreover, for their silence and compromise, the people believe that they have been bought over by MNOCs and the government. The people are fully aware of the consequences of pollution to their health and environment. They have adopted the violence measure as a medium of expressing their grievances. The people demand transparency and want to be 
carried along in the entire process of oil exploitation on their land. This entire atmosphere in the communities has created an ideology of distrust for the government and their own leaders. Thus, this has led to disregard for the usefulness of petroleum resources and a feeling of neglect.

\section{Recommendations}

Having successfully studied how the oil bearing communities in Ogoniland perceived the petroleum exploitation and pollution in their environment, we recommend that the multinational oil companies should massively developed their host communities. Government and multinational oil companies should always deal directly with the land owners whose portions of land have been directly affected by the pollution, and not through the chiefs or the CBOs. This is because this study has revealed that the monies paid for compensation of polluted lands, do not get to the actual land owners because of the chains or protocols for these payments. Multinational oil companies should, on a yearly basis, sign new MOUs and review previous MOUs with the host communities in an open and transparent forum that is accessible for all that want to attend. These will create a peaceful environment for the MNOCs to operate and build love of the host community for them as they will be seen to be accommodating. Thus, it is also very essential that the MNOCs provide basic amenities in all their host communities. These actions will encourage the communities to protect the resources in their environment and see it as being useful.

\section{References}

1. Aghalino, S. O. (2009). Corporate response to environmental deterioration in the oil bearing areas of Niger Delta, Nigeria, 19842002. Journal of Sustainable Development in Africa. 11 (2): 281-294.

2. Agbonofo, J. (2009) Development as conflict: Ogoni movement, the state and oil resources in Niger Delta, Nigeria, doctoral thesis, available (online) http://repub.eur.nl/res/pub/32647/90-42303808_DOK\%5B1\%5D. (Retrieved on the $5^{\text {th }}$ June, 2017)

3. Agwu, M.O. (2013). Community Participation and Sustainable Development in the Niger Delta. British Journal of Education, Society and Behavioural Science. 3(1): 33-46, 2013.

4. Akpabio, E.M. and Akpan, N.S. (2010). Governance and oil politics in Nigeria's Niger Delta: the question of distributive equity. Journal of Human Ecology. 30, 111-121.

5. Akpan N.S and Akpabio E.M (2009). Oil and conflicts in the Niger Delta region, Nigeria: Facing the facts. Journal of Social Development. 24(1): 1-10 
6. Andersen, J.J., and Ross, M.L. (2013). The big oil change: a closer look at the Haber- Menaldoanalysis. Comparative Political studies. 47(7): 993-1021

7. Auty, R. (1994b). "The resource curse thesis: minerals in Bolivian development, 1970-90” Singapore Journal of Tropical Geography, 15 (2): 20-40.

8. Auty, R. (2001a). (Ed.) "Resource abundance and economic development", Oxford: Oxford University Press.

9. Auty, R. (2001b). "Why resource endowments can undermine economic development: concepts and case studies", Paper Prepared for the BPAmoco Seminar, Lincoln College Oxford University, November 28-29.

10. Baghebo, M (2012). Petroleum and Energy Economics. Bayelsa: Kadmon Printing Press and Publishing House.

11. Baghebo, M. and Atima, T. O. (2013). The impact of petroleum on economic growth in Nigeria.Global Business and Economics Research Journal, 2(5): 102-115.

12. Bawa, S. and Mohammed, J. A. (2007). Natural Resource Abundance and Economic Growth in Nigeria. Central Bank of Nigeria Economic Review, 45(3): 25-32.

13. Bulmer-Thomas, V. (1994). "The economic history of Latin America since independence", Cambridge Latin American Studies, Vol.77, Cambridge University Press, New York.

14. Collier, P. \& Hoeffler, A. (2004). Greed and Grievance in Civil Wars, in: Oxford Economic Papers Nr. 4 (56), Pp. 563-595.

15. Dominic, A. (1999). The Petroleum Industry in Nigeria: Joint Operating Agreements, Memorandum of Understandings, Compensation and other Related Issues in Perspective. http://dspace.unijos.edu.ng/bitstream/10485/1469/1/The Petroleum Industry in Nigeria (Retrieved on $5^{\text {th }}$ July, 2016)

16. Eregha, P.B., and Mesagan, E.P., (2016). Oil resource abundance, institutions and growth:evidence from oil producing African countries. Journal of Policy Modeling 38(3): 603-609.

17. Ezirim, G. E. (2011). The Political Economy of the Resource Curse and Development in the Gulf of Guinea: Nigeria in Perspective. African Journal of Political Science and International Relations 5 (2): Pp. 6171.

18. Faleti, S. A. (2010) . Challenges of Chevron's GMOU Implementation in Itsekiri Communities of Western Niger Delta. IFRA Nigeria E-Papers. pp. 1-27.

19. Fields, G. (1989). "Change in poverty and inequality in the developing countries", World Bank Research Observer, Vol.4/2, pp.167/85. 
20. Frankel, J.A., (2010). The natural resource curse: a survey. Working Paper Series rwp10- 005, Harvard University, John F. Kennedy School of Government.

21. Gallimore, P. (1996). Confirmation Bias in the Valuation Process: A Test for Corroborating Evidence. Journal of Property Research, 13: 261-273

22. Gelb, A. and Associates (1988) Oil Windfalls: Blessing or Curse, New York: Oxford University Press

23. Harding, J. (2013). Qualitative Data Analysis from Start to Finish London, SAGE Publishers

24. James O. O. (2015). Oil Companies and Lethal Violence in Nigeria: Patterns mapping and Evolution (2006-2014). IFRA-Nigeria Working Papers Series, No. 44.

25. Karl, T. L., (2004). Oil-led development: social, political, and economic consequences. Encyclopedia Energy 4: 661-672.

26. Legbosi, S. (2007) "The Adverse Impacts of Oil Pollution on the Environment and Wellbeing of a Local Indigenous Community: The Experience of the Ogoni People of Nigeria" paper delivered to United Nations.

27. Lindlof, T. R., and Taylor, B. C. (2002). Qualitative Communication Research Methods, 2nd Edition. Thousand Oaks, CA: Sage.

28. Mikesell, R. (1997). "Explaining the resource curse, with special reference to mineral exporting countries." Resources Policy, Vol. 23, No. 4.

29. Mmon P. and Igbuku A. (2015) Challenges and Prospect of Environmental Remediation/Restoration in Niger Delta of Nigeria: The Case of Ogoniland. Journal of Energy Technologies and Policy. 5(1): $12-20$

30. Moffat, D. and Olof, O. (1995). Perception and reality: Assessing priorities for sustainable development in the Niger Delta, AMBIO:Journal of Human Environment, Vol. 24, Nos. 7-8, 527-538.

31. National Population Commission of Nigeria (2006).

32. Nwajiaku-Dahou, K. (2012). The Political Economy of Oil and 'Rebellion' in Nigeria's Niger Delta, Review of African Political Economy 39 (132): 295-313.

33. Nworgu B.G (2006) Educational Research: Basic Issues and Methodology. Nsukka University Trust Publishers.

34. Ogbanga M (2015) Assessment of Flood Hazard on Livelihood Activities of Rural Dwellers in Rivers State, Nigeria. Journal of Agriculture, Food and Environment. 11(4) 90-96.

35. Pérouse de Montcos, Marc-Antoine. (2014). Oil Curse, State instability, and Violence in Developing Countries: Theoretical Lessons for Nigeria. IFRA - Nigeria E-Papers: p.1-58 
36. Ross, M. L. (2001a) 'Does Oil Hinder Democracy?', World Politics 53 (April): 297-322

37. Sachs, J.D., Warner, A.M., (1995). revised 1997, 1999. Natural resource abundance and economic growth. National Bureau of Economic Research Working paper No. 5398, Cambridge, MA.

38. Sachs, J. D. and Warner, A. M. (1997). "Natural resource abundance and economic growth", Center for International Development and Harvard Institute for International Development, Harvard University, Cambridge MA.

39. Sachs, J. D and Warner, A.M (2001). The Curse of Natural Resources. Center for International Development, Harvard University, 79 JFK Street, Cambridge, MA 02138. European Economic Review 45 (2001) 827-838

40. Saro-Wiwa, K. (1995) Complete statement by Ken Saro-Wiwa to Ogoni Civil Tribunal, Available http://www.ratical.org/corporations/KSWstmt.html .

(online)

41. Shams, M. (1989). "The impact of oil revenues on OPEC economy", Rivista Internzionale di Scienze Economiche e Commerciali.

42. Tanee, F. B.; and Love, A. A. (2009). Effectiveness of Vigna unguiculata as a Phytoremediation Plant in the Remediation of Crude Oil Polluted Soil for Cassava (Manihot esculenta: Crantz) Cultivation. Journal of Applied Environmental Management. 13(1): 43-47.

43. Tsui, K. K., (2011). More oil, less democracy: Evidence from worldwide crude oil discoveries. Econ. J. 121 (551), 89-115

44. Ugochukwu, C. N. C. and Ertel, J. (2008). Negative impacts of Oil Exploration on Biodiversity Management in the Niger De area of Nigeria. Impact Assessment and Project Appraisal 26 (2): 139-147.

45. UNEP (2011). Environmental Assessment of Ogoniland. Nairobi, Kenya: United Nations Environment Programme.

46. Uzoagulu, E. A. (1998). Practical Guide to Writing Research Project Reports in Tertiary Institutions. Enugu: John Jacob's Classic Publisher's Limited.

47. Watts, M. (2009). Crude Politics: Life and Death on the Nigerian Oil Fields. In Niger Delta: Economies of Violence, Institute of International Studies, UC Berkeley, Working Paper No. 25: 1-27

48. Wright, G. and Czelutsa, J. (2002). "Resource-based economic growth, past and present", Stanford University Press. 